DOI 10.15290/cnisk.2020.01.08.06

\author{
EWAMAJ \\ https://orcid.org/0000-0002-7295-1759 \\ Uniwersytet Marii Curie-Skłodowskiej w Lublinie
}

\title{
Wzorzec kobiety w prasie dla katoliczek w Polsce międzywojennej: przypadek periodyku „Kuźniczanka” $(1931-1936)^{1}$
}

\begin{abstract}
Streszczenie
Celem artykułu było ukazanie wzorca osobowego kobiety w Polsce międzywojennej na przykładzie czasopisma „Kuźniczanka”, katolickiego organu prasowego Szkoły Domowej Pracy Kobiet w Zakopanem. Przedstawiono w nim historię edukacyjnej placówki założonej pod koniec XIX w. przez Jadwigę z Działyńskich Zamoyska, wybitna działaczkę społeczna, patriotkę, propagatorkę idei żeńskiego szkolnictwa gospodarczego. Zamoyska dokonała recepcji idei „szkół życia chrześcijańskiego” według metody zakonu oratorian. Swoim postępowaniem dała świadectwo wzorcowego życia kobiety zaangażowanej w pracę na rzecz dobra wspólnego.

Analiza zawartości czasopisma „Kuźniczanka” pozwoliła na poznanie sposobów kreowania i upowszechniania ideału kobiety, która w systemie patriarchalnym spełniała rolę społeczna uwarunkowana płcia, biologia, tradycja, wierzeniem religijnym. We wzorzec wkomponowane były cechy Jadwigi Zamoyskiej łączaccej katolicką duchowość z pragmatyzmem organizatorki życia domowego. Dbała o to, by praca pro bono była źródłem radości i szczęścia kobiet, które prowadziły pracę edukacyjna, wychowawczą, charytatywną.
\end{abstract}

1 Publikacja przygotowana/finansowana w ramach programu Ministra Nauki i Szkolnictwa Wyższego pod nazwa DIALOG w latach 2019-2021. Jest wynikiem udziału w projekcie badawczym pt. „Ośrodek badań historii kobiet”, nr 0016/DLG/2019/10. 
Na łamach czasopisma zamieszczano fragmenty jej memuarów, listów i rozmyślań o naukach płynących $z$ Ewangelii. Ponadto redaktorki i publicystki troszczyły się o to, by czytelniczki „Kuźniczanki” otrzymywały wiadomości o europejskich intelektualistach katolickich, o ich najnowszych publikacjach $z$ zakresu teologii, pedagogiki, psychologii. Informacje o uczennicach i absolwentkach Szkoły Domowej Pracy Kobiet zawierały praktyczne wskazówki dotyczące wzorca Polki, katoliczki, obrończyni wiary religijnej i promotorki patriotyzmu.

Słowa kluczowe: czasopismo religijne, katolicyzm, wzorzec kobiety, dydaktyzm społeczny

\title{
THE IMAGE OF THE IDEAL WOMAN IN “KUŹNICZANKA" (1931-1936) - THE INTERWAR POLISH PRESS FOR CATHOLIC WOMEN
}

\begin{abstract}
The purpose of the article was to show the image of the woman in the interwar Poland, based on "Kuźniczanka" (1931-1936), a Catholic magazine. The article presents the history of Szkoła Domowej Pracy Kobiet (School of House Work for Women), founded at the end of the 19th century by Jadwiga Zamoyska (née Działyńska) - an eminent social activist, a patriot and a Catholic. Her life was an example of an ideal life of a woman dedicated to work for the common good.

The analysis of "Kuźniczanka" let us find out how the image of the ideal woman was created. Especially when remembering that the interwar period society was patriarchal. The model woman's traits were based on Jadwiga Zamoyska's - a Catholic and a home life organizer. She was doing everything to assure that the free job of teaching, bringing up and charity was a source of joy for women. The magazine was publishing pieces of her journals, letters and thoughts on Gospel as a source of knowledge. Furthermore, the authors were assuring that the readers were receiving news about the European Catholic intellectuals - especially their articles about theology, pedagogy and psychology. There were also texts about pupils and graduates of Szkoła Domowej Pracy Kobiet - who were shown as examples of Polish women, Catholics, defenders of the faith and patriots.
\end{abstract}

Keywords: religious magazine, Catholicism, ideal woman, social teachings 


\section{Wprowadzenie}

Wzorce osobowe kobiet w Polsce międzywojennej znajdowały odzwierciedlenie w prasie „dedykowanej płci”. Tytułowa problematyka dała podstawę do zainteresowania się zagadnieniem modelujaccego wpływu mediów na osobowość, a może bardziej na planowane czy pożądane postawy i zachowania odbiorców poddawanych wpływowi słowa drukowanego. Tworzono ideał osobowy użyteczny w pracy wychowawczej. Znajdowało się w nim wyobrażenie cech, których oczekiwano po kobiecie rozumnie i celowo spełniajaccej funkcje katoliczki, obywatelki i patriotki oraz organizatorki życia domowego, żony i matki.

Wzmiankowana prasa „dedykowana płci” obejmowała ogół tygodników i miesięczników przeznaczonych dla kobiet, w tym także czasopiśmiennictwo dla katoliczek. W opracowaniach naukowych (monografiach, słownikach) poświęconych systematyce mediów nie było dostatecznie ujednoliconej i pełnej definicji pojęć związanych $z$ tym segmentem mediów. W literaturze przedmiotu uwidoczniła się labilność w kwestii delimitowania pojęć jak „prasa wyznaniowa”, „prasa kościelna”, „prasa katolicka”, „prasa katolików” czy „prasa dla katolików”. W słownikowym ujęciu prasy wyznaniowej wskazano, że tworzyły ja „czasopisma, których redagowaniem i wydawaniem zajmuja się głównie ludzie świeccy zwiazani $z$ danym wyznaniem”2 . Do grupy prasy kościelnej zaliczono „oficjalna prasę informacyjno-ideową będącą zazwyczaj organem Kościoła Powszechnego, diecezji, parafii lub zakonu"3. Pod pojęciem prasy katolickiej rozumiano „te wydawnictwa, które za zgodą władz kościelnych drukowane sa periodycznie i rozpowszechniane publicznie w celu wszechstronnego ukazywania rzeczywistości, a zwłaszcza aktualnych zdarzeń i problemów z życia Kościoła oraz jego doktryny"4. Podobnie nie było

\footnotetext{
2 Sylwester Dziki, „Prasa wyznaniowa”, w: Walery Pisarek (red.), Słownik terminologii medialnej, (Kraków: Towarzystwo Autorów i Wydawców Prac Naukowych „Universitas”, 2006), 156; Czesław Lechicki, „Prasa kościelna, prasa religijna, prasa wyznaniowa”, w: Julian Maślanka (red.), Encyklopedia wiedzy o prasie, (Wrocław: Zakład Narodowy im. Ossolińskich, 1976), 174, 182, 191.

3 Marek Gloger, „Prasa parafialna”, w: Edward Chudziński (red.), Słownik wiedzy o mediach, (Warszawa: Wydawnictwo Szkolne PWN, 2007), 149.

4 Adam Lepa, Katalog prasy katolickiej w Polsce, (Łódź: Archidiecezjalne Wydawnictwo Łódzkie, 1994), 3; Czesław Lechicki, „Polska prasa katolicka 1945-1948”, Kwartalnik Historii Prasy Polskiej, nr 2, 1983, 65-84. Można też przytoczyć szersze podejście do problemu i wtedy pod pojęciem mediów katolickich znajdują się „masowe oraz odmasowione środki przekazu (prasa, radio, telewizja, media w środowisku sieciowym), które kieruja
} 
ustalonej nomenklatury w Polsce międzywojennej, stąd w Spisie gazet i czasopism Rzeczypospolitej Polskiej prasę konfesyjna sytuowano w rubryce Kościelne i religijne. W krótkim czasie uwidocznił się przyrost tego typu czasopiśmiennictwa. W spisie z 1922 r. rubryka zawierała zestaw 53 periodyków, dwa lata później ich liczba wzrosła do 62 pozycji, wśród których poza nielicznymi wyjątkami (przykładowo, prasa ewangelików czy periodyki mariawitów) znajdowała się prasa katolicka, a w początkach 1932 r. było 150 czasopism kościelnych i religijnych ${ }^{5}$. Ich istnienie było następstwem wykonania postanowień encykliki Etsi nos, która 15 lutego 1882 r. ogłosił papież Leon XIII, zachęcając do kreowania prasy propagującej wartości chrześcijańskie. Doświadczenia wydawnicze z następnych lat wskazywały na wychowawczą i edukacyjna funkcję czasopiśmiennictwa dla katolików.

Celem opracowania było zrekonstruowanie modelu kobiecości wykreowanego w szczególnych warunkach komunikacyjnej działalności konkretnego periodyku promującego religijny system aksjologiczny. Decyzji o użyciu pojęcia „prasa dla katoliczek” towarzyszyła dążność do delimitowania docelowej grupy czytelniczej. W poniższym tekście znalazły się odpowiedzi na pytania o wzorzec postaw i zachowań kobiet w Polsce międzywojennej zdeterminowany przez wartości religijne i umieszczony w materiałach prasowych dla katoliczek. Zwrócono uwagę na komponenty ideału wychowawczego takie, jak dobra katoliczka i obywatelka oraz dobra organizatorka życia codziennego i animatorka pracy domowej, co implikowało kształt strukturalny artykułu. Język cytatów został dostosowany do dzisiejszych wymogów gramatycznych i ortograficznych, jedynie zachowano oryginalne nazewnictwo ,jenerałowa” bądź „generałowa”,

się zasadą eklezjalności, tj. funkcjonują za zgodą lub przy poparciu kompetentnej władzy kościelnej, sa rozpowszechniane w celu wszechstronnego oglądu rzeczywistości, w tym informacji z życia Kościołów lokalnych oraz Kościoła powszechnego, ponadto reprezentuja dziennikarstwo oparte na zasadach katolickich w obszarze komunikacji”, Damian Guzek, Media katolickie w polskim systemie medialnym, (Torun: Wydawnictwo Adam Marszałek, 2016), 24; Jan Chrapek, „Kościół wobec środków społecznego komunikowania”, Ethos, nr 4, 1989, 230-245; Marek Sokołowski (red.), Blask religii. Media w poszukiwaniu sacrum $i$ autorytetów, (Torun: Wydawnictwo Adam Marszałek, 2016), 10-11.

5 Spis gazet i czasopism Rzeczypospolitej Polskiej 1922, (Warszawa: Biuro Ogłoszeń Polska Agencja Reklamy, 1922), 102-103; Spis gazet i czasopism Rzeczypospolitej Polskiej oraz poradnik reklamowy. Rocznik 1924/25, (Warszawa: Biuro Ogłoszeń Teofil Pietraszek, 1924), 97-99; Spis gazet i czasopism Rzeczypospolitej Polskiej oraz poradnik reklamowy na rok 1932, (Warszawa: Biuro Ogłoszeń Teofil Pietraszek, 1932), 125-127. 
a także niezmienioną tytulaturę czasopisma „Pod Znakiem Marji” celem oddania klimatu epoki historycznej.

\section{Periodyk „Kuźniczanka”: geneza i cechy}

W Polsce międzywojennej prasa dla katoliczek miała reprezentację w postaci organów stowarzyszeń społecznych takich, jak: Katolickie Stowarzyszenie Kobiet („Własnymi Siłami”), Stowarzyszenia Katolickich Kobiet i Dziewczat Pracujacych („Kobieta Polska”), Zjednoczenie Katolickich Zwiazków Polek („Zjednoczenie”), Zjednoczenie Stowarzyszeń Młodzieży Polskiej („Młoda Polka”), Związek Kobiet Katolickich („Doniesienia Zwiazkowe Zwiazku Kobiet Katolickich”), Zwiazek Stowarzyszeń Kobiet Pracujących („Gazeta dla Kobiet”). Były też dodatki prasowe: „Niewiasta Polska” (dodatek miesięczny do „Naszego Kraju”). Prywatnym nakładem w Krośnie, a potem w Krakowie ukazywał się też periodyk o tej samej nazwie „Niewiasta Katolicka”. Istniał segment periodyków sodalicyjnych, przykładowo, ukazujący się w Zakopanem miesięcznik „Pod Znakiem Marji”, organ Związku Sodalicji Mariańskich w Polsce.

Zakopane (a dokładniej Zakopane-Kuźnice) było miejscem wydawania czasopisma „Kuźniczanka”, które ukazywało się nakładem Stowarzyszenia Chrześcijańsko-Społecznego pod opieka Matki Boskiej Dobrej Rady ${ }^{6}$. Stowarzyszenie założyła Jadwiga Zamoyska $z$ Działyńskich w 1881 r. w Paryżu. Następnie rozwijała działalność na ziemiach polskich wraz ze swoja córką Marią Zamoyską oraz z pomocnica Julią Zaleską. Poprzednik „Kuźniczanki” pod nazwa „Pisemko Kuźniczanek” wychodził pod firmą: Zakład Kórnicki - Szkoła Domowej Pracy Kobiet (SDPK) w Zakopanem. Został reaktywowany w lutym 1924 r. po dziesięcioletniej przerwie i istniał do końca $1930 \mathrm{r}$. Miał dwa cele, po pierwsze, integrowanie obecnych i dawnych uczennic. Po drugie, zmierzano do „ożywienia w nich ducha, jakiego w Zakładzie nabrały"7. Redaktorka naczelną była Julia Strawińska, następnie Aniela Strawińska, ale faktyczne kierownictwo pisma sprawowała Małgorzata Hube, nazywana „wzorem mężnej niewiasty", gdyż z oddaniem dbała o sprawy SDPK oraz o dobro słuchaczek ${ }^{8}$.

\footnotetext{
6 Jacek Lachendro, „Prasa powiatów górskich województwa krakowskiego w latach 1918-1939", Rocznik Historii Prasy Polskiej, nr 3, 2000, 48.

7 Pisemko Kuźniczanek, nr 1, 1924, 1.

8 We wspomnieniach nadmieniano, że „Pisemko Kuźniczanek", którego przez lat kilka była redaktorką, spełniało doskonale swoje zadanie. Było łącznikiem z Zakładem i umacniało w zasadach wyniesionych z Kuźnic".
} 
Była znana $z$ opiekuńczych działań na rzecz społeczności szkolnej, wspierała moralnie i finansowo niezamożne uczennice, pomagając im w uzyskaniu praktycznego wykształcenia zawodowego. Wydawczynie i redaktorki musiały dopełnić formalności rejestracyjnych, co w $1925 \mathrm{r}$. skutkowało zmiana charakteru pisma $z$ manuskryptowego na ogólnie dostępny miesięcznik. Jednak zastrzegano, że nadal było skierowane do zamkniętego grona wychowanek Szkoły ${ }^{9}$. Śmierć Małgorzaty Hube 29 maja 1930 r. spowodowała czasowe zawieszenie wydawnictwa, co potwierdzało jej znaczenie w kierowaniu praca periodyku, mimo braku formalnego zapisu w stopce redakcyjnej. W numerze datowanym na listopad-grudzień 1930 r. tłumaczono powody paromiesięcznej przerwy, którą rozpoczęła „śmierć kochanej naszej p. Hube. Ona to od 5-ciu lat zajmowała się całkowicie zarówno pracą redakcyjna, jak i administracyjną"10. Do edycji pisma powrócono w styczniu 1931 r., ale pod zmienionym tytułem jako miesięcznik „Kuźniczanka”. Zmiana zyskała aprobatę hierarchów kościelnych. Szczególną wymowę miał list biskupa Stanisława Adamskiego do redakcji periodyku ${ }^{11}$. Uznał, że zmiana była korzystna dla pogłębienia pracy propagandowej na rzecz idei Stowarzyszenia.

W winiecie pisma „Kuźniczanka” znajdowało się motto: Służyć Bogu, służac Ojczyźnie. Na stronie okładkowej eksponowano znak szkoły, na który składały się: krzyż, kądziel i książka, stanowiące klarowne symbole wierzenia religijnego, domowej pracy kobiecej oraz dążności do pozyskania wiedzy o rzeczywistości społecznej, w której miały żyć wychowanki po opuszczeniu SDPK. W nowym czasopiśmie śladem po poprzedniku była numeracja roczników - styczniowy numer został oznaczony jako rocznik 11, co oznaczało kontynuację „Pisemka Kuźniczanek”. Niezmieniony pozostał ogólny kształt czasopisma oraz jego struktura wewnętrzna, szczególnie główna część, która każdorazowo była poświęcona postaci „Jenerałowej Zamoyskiej”, czyli Jadwigi Zamoyskiej, twórczyni SDPK w Zakopanem. Jej „świetlana postać” towarzyszyła czytelniczkom w każdym numerze „Pisemka Kuźniczanek” oraz „Kuźniczanki”12.

\footnotetext{
9 „Od Redakcji”, Pisemko Kuźniczanek, nr 3, 1925, 28.

10 „Od Redakcji”, Pisemko Kuźniczanek, nr 11-12, 1930, 67; „Śp. Małgorzata Hube”, Pisemko Kuźniczanek, nr 5-6, 1930, 49-51. Pisano, że była „duszą naszego wydawnictwa”, która trudno było zastapić w pracy redakcyjnej.

11 „List Najprzewielebniejszego Księdza Biskupa Adamskiego”, Kuźniczanka, nr 2, 1931, 25.

12 Michalina Grodzicka, „W setną rocznicę urodzin Generałowej Zamoyskiej”, Kuźniczanka, nr 7-8, 1931, 137-149; „Z nauk śp. Generałowej Jadwigi Zamoyskiej. O naszych
} 
W 1934 r. zmieniła się częstotliwość wydawnicza czasopisma, zamiast miesięcznika był kwartalnik. Unowocześnieniu ulegała szata graficzna, ponieważ stopniowo zaczęto wprowadzać ilustracje w postaci rysunków (portret Marii Zamoyskiej) oraz fotografii, głównie przedstawiających panoramę Kuźnic. Na początku redaktorka naczelną była Aniela Strawińska, a potem od numeru 9 we wrześniu 1931 r. Janina Strawińska, która zadbała o stabilna pracę wydawniczą. Dopiero jej zaangażowanie w sprawy organizacyjne Katolickiego Zwiazku Kobiet (KZK) w Poznaniu sprawiło, że w 1935 r. nie ukazały się trzy numery pisma, co spowodowało konieczność odredakcyjnego wyjaśnienia powodów takiego stanu. $\mathrm{W}$ formie usprawiedliwienia się przed prenumeratorkami w pierwszym numerze z 1936 r. podano, że braki wynikały z nieobecności Janiny Strawińskiej i nagłego wyjazdu redaktorki, która przez prymasa Polski Augusta Hlonda została mianowana dyrektorką $\mathrm{KZK}^{13}$. Dwa lata po tym wydarzeniu ukazał się numer specjalny w całości poświęcony pamięci Marii Zamoyskiej, córce i kontynuatorce dzieła Jadwigi Zamoyskiej.

Po zmianie częstotliwości publikacyjnej czasopismo stosowało różny sposób numerowania i datowania poszczególnych edycji, przykładowo, zamiast daty miesięcznej była informacja typu „zima-wiosna” czy „latojesień”. Zdarzały się błędy techniczne w postaci niespójności między spisem treści a tytułem tekstu w zasadniczej części periodyku, np. w spisie anonsowano, że na stronie pierwszej umieszczona została Odezwa „do czytelniczek", a faktycznie na tej stronicy był tekst Do Czytelniczek. W informacjach o autorstwie tekstu również pojawiały się rozbieżności, gdy w spisie treści tekst sygnowano inicjałami (przykładowo JS), a właściwy materiał był podpisany imieniem i nazwiskiem (w tym wypadku Janiny Strawińskiej). Pod względem genologicznym uwidoczniła się stałość gatunkowa tekstów przy wzmiankowanej powtarzalności publikowania memuarów Jadwigi Zamoyskiej, a także felietonów (na ogół autorstwa redaktorki naczelnej), gawęd, sprawozdań, kronik bieżących wydarzen, omówień książek zalecanych do lektury czytelniczkom „Kuźniczanki”.

obowiąkach względem duchowieństwa”, Pisemko Kuźniczanek, nr 7-8, 1930, 68-71; „Pamiętnik P. Generałowej”, Pisemko Kuźniczanek, nr 7-8, 1930, 72-76; „Pamiętniki Jenerałowej Zamoyskiej. Paryż - obowiązki rodzinne”, Kuźniczanka, nr 2, 1934, 25-32.

13 Redakcja, „Do Czytelniczek”, Kuźniczanka, nr 1, 1936, 1. Janina Strawińska brała czynny udział w działalności Akcji Katolickiej. Animowała ruch katoliczek, uczestnicząc w ogólnopolskich zjazdach, naradach, kursach, w trakcie których wygłaszała referaty o strukturze organizacyjnej KZK i członkiniach Zwiazku, „Sprawozdanie z kursu dla kierowników w Lublinie", Ogniwo, nr 3, 1937, 7. 
Funkcja informacyjna była realizowana poprzez druk materiałów dotyczących wydarzeń bieżących, np. ogłoszenie odezwy w sprawie finansowego wsparcia Katolickiego Uniwersytetu Lubelskiego ${ }^{14}$. Co pewien czas organizowano ankietowanie odbiorczyń periodyku $z$ wykorzystaniem dwóch obszarów tematycznych: (1) sfery duchowości katolickiej - ankieta pod nazwą Rozmyślanie $w$ naszym życiu - ogłoszona na początku 1933 r., (2) sfery praktyczności edukacji szkolnej - w postaci odpowiedzi na pytanie: Co mi dały Kuźnice? - ankieta z 1934 r. Ponad zwyczajowymi komponentami właściwymi dla stereotypowo postrzeganego czasopisma dla kobiet znajdowała się rubryka pod nazwą Zawiadomienia. Zamieszczano w niej informacje o zawarciu związków małżeńskich przez dawne wychowanki Szkoły. Nie było innych rubryk uznawanych za charakterystyczne dla prasy ukierunkowanej na kobiety w rodzaju działów poświęconych modzie ubraniowej, nowinkom kosmetycznym, poradnictwu w zakresie podstawowej ochrony zdrowia czy regułom lifestylowego funkcjonowania „nowoczesnej” pani uprawiajacej sporty typu automobilizm, pływanie, tenis ${ }^{15}$. Dopiero w 1936 r. (od drugiego numeru) redakcja „Kuźniczanki” podjęła decyzję o wprowadzeniu Działu wskazówek praktycznych, w którym czytelniczki mogły się wymieniać przepisami kulinarnymi.

Pismo było ukierunkowane na słuchaczki i absolwentki SDPK, ale miało też odbiór powszechny, znajdując się w ogólnym obiegu czytelniczym. Świadczyła o tym rekomendacja przedstawiona przez Towarzystwo Wydawnicze „Bluszcz” w 1939 r., w której „Kuźniczanka” została wymieniona $\mathrm{w}$ gronie najbardziej popularnych czasopism dla kobiet polecanych czytelniczkom w całej Polsce ${ }^{16}$. W SPDK według planu Jadwigi Zamoyskiej kształcono uczennice w zakresie prowadzenia gospodarstwa domowego, ale też ogłady towarzyskiej, zmierzano do umocnienia patriotyzmu, a nade wszystko do doskonalenia pobożności ${ }^{17}$.

\footnotetext{
14 S., „Dla katolickiej uczelni”, Kuźniczanka, nr 3, 1933, 59; „Odezwa w sprawie Katolickiego Uniwersytetu Lubelskiego”, Kuźniczanka, nr 2, 1934, 44.

15 Periodyk „Kuźniczanka” nie stanowił wyjątku pod względem braku działów stereotypowo przypisanych płci, zob.: Ewa Maj, „Kobieta wobec polityki: strategie tożsamościowe w publicystyce tygodnika Na Posterunku (1917-1919)", w: Małgorzata Dajnowicz, Adam Miodowski (red.), Polityka i politycy $w$ prasie XX $i$ XXI wieku. Polityka $w$ prasie kobiecej, (Białystok: Wydawnictwo Uniwersytetu w Białymstoku, 2019), 43-56.

16 „Prasa kobieca. (Historia i stan obecny)”, Kalendarz Dla Kobiet Na rok 1939, 1939, 58.

17 Jadwiga Zamoyska, Zakład Kórnicki. (Szkoła Domowej Pracy w Zakopanem), (Poznań: Biblioteka Kórnicka, 1898); eadem, Zakład Kórnicki. (Szkoła Domowej Pracy w Zakopanem). O trzech oddziałach, (Poznań: Biblioteka Kórnicka, 1900); M.C., „Społeczne znaczenie domu”, Kuźniczanka, nr 1, 1934, 13-14; zob.: Mariola Bogumiła Bednarz, „Hrabina
} 
W programie nauczania obok standardowego zestawu zajęć, jak: język polski, matematyka, geografia, historia, religia, były zajęcia związane $z$ prowadzeniem gospodarstwa domowego. Pod auspicjami Stowarzyszenia działały cztery placówki: Szkoła Domowej Pracy Kobiet Zakopane-Kuźnice, Szkoła Domowej Pracy Kobiet w Kórniku pod Poznaniem, Szkoła Gospodarstwa Domowego im. Generałowej Zamoyskiej w Warszawie, od września 1932 r. Szkoła Zarządczyń im. Generałowej Zamoyskiej w Warszawie. W materiałach rekrutacyjnych informowano, że od kandydatki do Szkoły wymagano wykształcenia: „od VI klasy szkoły średniej”, podobne wymagania stawiano przed przyjęciem do szkoły warszawskiej.

Jeszcze większe oczekiwania miano wobec kandydatek do Szkoły Zarządczyń, od których wymagano ponadto ukończenia szkoły gospodarczej. Z kolei przy rekrutowaniu do SDPK w Kórniku wystarczyło zaliczenie nauki na poziomie szkolnictwa powszechnego. We wszystkich wypadkach nabór dotyczył rocznego kursu. W Kuźnicach i w Warszawie oferowano nauczanie w zakresie spraw gospodarstwa domowego: gotowania, kroju i szycia, porządków, prania, prasowania, a także przedmiotów teoretycznych.

Z kolei placówka kórnicka w programie zajęć miała: kucharstwo, mleczarstwo, „gospodarstwo podwórzowe”, pranie i prasowanie, porzadki domowe, krój i szycie, przedmioty zawodowe i dokształcajace. Bardziej wyszukany charakter cechował Szkołę Zarządczyń, przy czym w prospekcie reklamowym zapisano, że była pierwszą w Polsce tego typu placówką „na wzór szwajcarski” ${ }^{18}$.

Dla absolwentek przewidywano możliwości zatrudnienia w sanatoriach, szpitalach, pensjonatach i innych placówkach o charakterze opiekuńczym i terapeutycznym. $Z$ materiałów przesyłanych przez dawne wychowanki wynikało, że podejmowały pracę zawodowa w szkolnictwie i w zakładach wychowawczych. Jedna z „kuźniczanek” była Zofia Żelska-Mrozowicka, ceniona dziennikarka prasowa i działaczka społeczna ${ }^{19}$. Miała pochodzenie ziemiańskie, ale słuchaczkami kursów „w $75 \%$ były

Jadwiga Zamoyska: założycielka Kuźnickiej Szkoły”, Karkonosze, nr 2, 2011, 32-33; Katarzyna Czachowska, Generałowa Jadwiga Zamoyska (1831-1923). Życie i dzieło, (Poznań: Wydawnictwo Poznańskie, 2011).

18 Kuźniczanka, nr 3, 1936, bez paginacji; „Program Szkoły Zarządczyń im. Generałowej Zamoyskiej”, Kuźniczanka, nr 6, 1932, 97-100.

19 „Żelska-Mrozowicka Zofia”, w: Grażyna Bral (red.), Słownik dziennikarzy i publicystów Pomorza 1945-2005, (Gdańsk: Stowarzyszenie Dziennikarzy Rzeczypospolitej Polskiej, 2008), 197. 
... dziewczęta $z$ ludu. Córki rolników, rzemieślników, robotników. Córki ziemian, kupców i tak zwanych wolnych zawodów stanowiły zaledwie $25 \%$. Szkoła miała więc ustrój na wskroś demokratyczny i społeczny. Założycielce chodziło o to, by podźwignąć od podstaw kraj, który wskutek wieloletniej niewoli tonął w nędzy i ciemnocie, i przyjść z pomocą całemu społeczeństwu. Tak więc u podnóża Tatr spotykała się młodzież z całej Polski i ze wszystkich warstw społecznych"20.

Teksty publikowane w periodyku były przygotowane przez redaktorki, współpracownice oraz przez członkinie społeczności szkolnej. W wyjatkowych wypadkach posługiwano się materiałami pozyskanymi z Katolickiej Agencji Prasowej (KAP), głównie w odniesieniu do teologicznych rozważań prawd wiary. Czasopismo spełniało wymogi religijnego, katolickiego periodyku dla kobiet, ale też przynajmniej po części było pismem szkolnym, ponadto miało cechy biuletynu organizacyjnego zawierającego materiały sprawozdawcze $z$ życia stowarzyszenia.

\section{Sfera ducha: dobra katoliczka}

Na łamach pisma „Kuźniczanka” prezentowano „wzorzec roli”, który był wkomponowany w obraz kobiety formułującej priorytety życiowe według wymogów wierzenia religijnego. Kreowano personalny ideał kobiecości godnej naśladownictwa, ponieważ postępowała zgodnie $z$ zasadami Dekalogu i w duchu troski o bliźniego. W pojęcie „wzorca roli” wkomponowane były cechy osoby, będacej „dla jednostki wzorem, na podstawie którego kształtuje ona własne zachowanie związane $z$ konkretna rolą społeczną"21. Postać Jadwigi Zamoyskiej, wybitnej Polki, przedstawicielki historycznego rodu, aktywnej uczestniczki pracy społecznej, animatorki instytucji pożytku publicznego, świetnie nadawała się do upowszechniania ideału wychowawczego mającego ukształtować osobowości przedstawicielek młodej generacji dziewcząt i kobiet.

\footnotetext{
20 Mieczysława Czaplicka, Moje wspomnienia. Szkoła Pracy Domowej w Zakopanem-Kuźnicach, (Kraków: Wydawnictwo Instytutu Teologicznego Księży Misjonarzy, 1964), 198. Uczennice $z$ uboższych środowisk, otrzymujące stypendia na codzienne utrzymanie, w $1931 \mathrm{r}$. straciły możność pobierania nauki w placówce kuźnickiej z powodu kłopotów finansowych Fundacji Kórnickiej spowodowanych wielkim kryzysem gospodarczym. Informację podano do wiadomości publicznej, „Kronika. Redukcja kursów”, Kuźniczanka, nr 3, 1931, 52.

${ }^{21}$ „Wzorzec roli, model roli”, w: Maxine Molineux et al., Stownik socjologii i nauk społecznych, red. Gordon Marshall, red. nauk. wyd. pol. Marek Tabin, red. Alina Kapciak, tłum. Henryk Banaszak, (Warszawa: Wydawnictwo Naukowe PWN, 2005, 432.
} 
Autorytet Jadwigi Zamoyskiej potwierdzał się w jej słowach systematycznie publikowanych celem uwznioślonego oddziaływania na czytelniczki. Drukowane były teksty zawierające memuary Zamoyskiej, w tym pamiętniki, listy, rozmyślania. Prowadzono stałe rubryki: Pamiętniki Generałowej Zamoyskiej czy Życie chrześcijańskie (Z rozmyślań Generałowej Zamoyskiej), O duchu pokuty: z nauk Generałowej Zamoyskiej, w których przytaczano kolejne fragmenty pisarskiej spuścizny założycielki i duchowej patronki Szkoły oraz obydwu czasopism „Pisemka Kuźniczanki” oraz „Kuźniczanki”. Upowszechniano wiedzę o jej rozważaniach na temat Pisma Świętego, przywoływano in extenso niektóre sentencjonalne uwagi i komentarze do żywotów świętych ${ }^{22}$. Frekwencyjna obecność nazwiska fundatorki potwierdzała, że była osobą znacząca dla społeczności, co skutkowało następującymi działaniami: 1) konstruktywnym prezentowaniem cech godnych odwzorowania; 2) efektywnym kontrolowaniem oddziaływania personalnego ideału na postawy i zachowania uczennic; 3) uaktywnianiem słuchaczek w celu wypełniania konkretnych powinności wobec wspólnoty; 4) kreowaniem warunków wsparcia dla osób słabszych. Ponadto redakcja pisma zmierzała do zaspokajania potrzeby współpracy w dziele rozwijania i umacniania relacji między członkiniami społeczności.

Wypełniając funkcję perswazyjna, „Kuźniczanka” prowadziła edukację religijna, która pozwalała połączyć wiedzę zaczerpniętą z Ewangelii $z$ nauczaniem o postawie patriotycznej i obywatelskiej. W odredakcyjnych tekstach przypominano: „Trzeba, aby każda Kuźniczanka w myśl zasad p. Generałowej Zamoyskiej praca i oszczędnościa nawet w najdrobniejszych rzeczach przyczyniała się do budowy Zmartwychwstałej Polski"23. Ideał życia pracowitego i skromnego stanowił punkt odniesienia do działań edukacyjno-wychowawczych, które przetrwały i umacniały się dzięki osobowości patronki. Zostały utrwalone i miały dalszą moc oddziaływania mimo śmierci Zamoyskiej w 1923 r. Wykształciła swoje następczynie w dziele wychowywania młodych dziewczat, czyli Małgorzatę Hube i Julię Zaleska, łączące swoje życie $z$ „ideałem, wysiłkiem i trudem swej

22 Jadwiga Zamoyska, Słowa Pisma Świętego podane do rozmyślania. 3, (Leviticus: Księga Kapłańska), (Poznań: Zakład Kórnicki, 1918); Maria Zamoyska, Jak powstało dzieło śp. Jenerałowej Zamoyskiej, (Kórnik: Zakłady Kórnickie, 1927).

${ }^{23}$ Kuźniczanka, nr 1, 1931, 21; „Nasze zadanie”, Kuźniczanka, nr 3, 1931, 49-52. 
Mistrzyni"24. Zgodnie z zaleceniami Zamoyskiej czytelniczki otrzymywały przekaz dotyczący sposobu działania dobrej katoliczki, która powinna posiadać solidne i trwałe podstawy wiedzy religijnej. Jednak limitowano obraz wyłącznie kontemplacyjnego charakteru refleksyjności katoliczek, ponieważ „to nie jałowe rozmyślania, nie dewocyjny sentymentalizm religijny" miał tworzyć wzorzec kobiety ${ }^{25}$. Nauki religijne przekładano na działania codzienne tak, by wskazania konfesyjne znajdowały miejsce w twórczości naukowej i artystycznej ujawniającej „głęboką mądrość Bożą" osób, które dążyły ku duchowym wyżynom w ramach samodoskonalenia. Dobra katoliczka miała być aktywna w dziele pracy dla dobra wspólnego, przypominano, że Jadwiga Zamoyska określała siebie mianem „żołnierza Bożego”26.

W zawartości periodyku sporo było wspomnień o przeszłości narodu i państwa. $Z$ pamiętników Zamoyskiej przedrukowano liczne i drobiazgowe informacje o życiu Wielkiej Emigracji po powstaniu listopadowym. Pisała o Adamie Jerzym Czartoryskim i działalności grupy Hotel Lambert. Wypowiadała się o patriotyzmie Czartoryskiego i jego wizji odrodzenia suwerennej Polski oraz podjętej pracy organizatorskiej służącej realizacji planu odrodzenia państwa. Wzmiankowała o bogactwie biograficznych doświadczeń polityka, który uczestniczył w ważnych wydarzeniach w skali europejskiej i polskiej. Ze wzruszeniem opisywała ostatnie chwile Czartoryskiego, samokrytycznie wypowiadając się o własnej postawie: ,jakże często teraz żałuję mojego nieuctwa, które było powodem, że nie umiałam korzystać $z$ jego rozmowy, jak mogłabym to uczynić"27. Jej postawa świadczyła o gotowości do ujawniania cech zwyczajnej osoby, która miała słabości i niedostatki charakterologiczne, ale też zawierała przekaz dydaktyczny w postaci przypomnienia, że w obcowaniu $z$ niezwykłym człowiekiem należało zatroszczyć się o zapamiętanie jego słów i zapisywanie ich dla potomności. Pod tym względem generałowa Zamoyska okazywała się skrupulatną dokumentalistką zdarzeń z przeszłości.

\footnotetext{
24 „Hołd półwiekowej pracy”, Kuźniczanka, nr 1, 1933, 9. Julia Zaleska w 1932 r. została odznaczona Srebrnym Krzyżem Zasługi. Na stanowisku przełożonej w 1936 r. zastapiła ją Józefa Łyskowska.

${ }_{25}$ „Z życia Szkoły Gospodarstwa Domowego im. Generałowej Zamoyskiej w Warszawie”, Kuźniczanka, nr 1-2, 1935, 16.

26 „Ku wyżynom (Wspomnienie o śp. Helenie Sozańskiej)”, Kuźniczanka, nr 4, 1933, 81 82; „Z nauk Generałowej Zamoyskiej. O duchu pokuty”, Kuźniczanka, nr 3, 1931, 60.

27 „Pamiętniki Generałowej Zamoyskiej. Ostatnie chwile Księcia Jerzego Czartoryskiego”, Kuźniczanka, nr 3, 1933, 56.
} 
Dlatego wiarygodnie brzmiały jej zalecenia dla każdej dziewczyny i kobiety, by podejmowały się samokształcenia, ponieważ „umysł, który się nie kształci, rdzewieje i słabnie. Trzeba codziennie godzinę, a co najmniej pół godziny poświęcić dla własnej nauki”28. Przypominała: ,jeżeli z powodu nadmiaru pracy materialnej, mając mało czasu, zaniedbujemy ćwiczenia umysłu, staniemy się jakby martwymi maszynami”29. Dla ćwiczenia umiejętności zapamiętywania zalecała naukę na pamięć modlitw i tekstów pieśni religijnych. Co więcej, zachęcała do przyswojenia modlitw w dwóch językach: po łacinie i po polsku, wskazując na funkcjonalny i moralny charakter tego rodzaju umiejętności.

W treści „Kuźniczanki” niemal nie było informacji o działaniach administracji publicznej państwa polskiego (pojedynczo pojawiały się wzmianki o nabożeństwach $z$ intencja „o pomyślne wybory”), a wiadomości z zagranicy zostały zredukowane do wzmianek na temat wybranych form aktywności międzynarodowych organizacji religijnych i ich kierownictwa oraz efektów pracy społecznej. O sprawach wewnatrzpaństwowych pojawiały się pośrednie informacje poświęcone niektórym wydarzeniom o patriotycznej wymowie. Konkretny przekaz informacyjny odbywał się w kontekście ważnych rocznic historycznych i przy wypełnianiu funkcji wychowawczo-edukacyjnej. Na poczatku $1931 \mathrm{r}$. w zwiąku $z$ rocznica wybuchu powstania listopadowego opublikowany został tekst pod tytułem Dzień 29 listopada w Kuźnicach. Przedstawiono przebieg uroczystości, w jakich uczestniczyły wychowanki Szkoły, w tym udział $\mathrm{w}$ nabożeństwie $\mathrm{w}$ intencji Ojczyzny $\mathrm{z}$ chóralnym śpiewem pieśni religijnych i patriotycznych (Bogarodzica, Boże, coś Polskę, Przez wiek cały zapomniani), potem w uroczystej akademii w Zakopanem, a następnego dnia w przedstawieniu przygotowanym przez słuchaczki SPDK. Widzowie obejrzeli inscenizację teatralna z deklamacjami wierszy poświęconych powstaniu i jego bohaterom. Wspomniano też o uczestnikach innych walk o Polskę, w tym również w wojnie z bolszewikami w 1920 r. Dla oddania nastroju towarzyszaccego informowano czytelniczki, że „nasze artystki grały z przejęciem i odczuciem roli. Całość więc wywołała podniosły nastrój”30. Szczególna atmosfera towarzyszyła też innym wydarzeniom,

28 „Życie chrześcijańskie (Z rozmyślań Generałowej Zamoyskiej)”, Kuźniczanka, nr 2, 1934, 32.

29 Ibidem, 33.

30 Władysława Skibińska, „Kronika. Dzień 29 listopada w Kuźnicach”, Kuźniczanka, nr $1,1931,21$. 
w których brały udział słuchaczki Szkoły, a dowiadywały się o nich odbiorczynie pisma. W 1931 r. przypadała setna rocznica urodzin Jadwigi Zamoyskiej oraz pięćdziesiąta rocznica założenia placówki wychowawczej, co uczczono wielkim zjazdem 31 maja 1931 r. zorganizowanym przez Poznańskie Koło Kuźniczanek.

Wizerunek kobiety mieścił w sobie wyobrażenie osoby czynnej, poświęcającej się dla dobra wspólnego, przygotowanej do sumiennej i odpowiedzialnej działalności społecznej. Janina Strawińska w obszernym artykule (liczacym ponad sześć stronic) Społeczne urabianie młodzieży przedstawiła zagadnienie pracy społecznej i przyuczenia do niej młodego pokolenia. Podstawę rozważań dała jej encyklika Divini illius Magistri (O chrześcijańskim wychowaniu młodzieży) papieża Piusa XI z 31 grudnia 1929 r. Oceniła przebieg procesów socjalizacji młodego pokolenia przez pryzmat roli w rodzinie, w środowisku koleżeńskim, w otoczeniu społecznym, w którym niezbędne było dopełnienie zadań wychowawczych przez trzy instytucje: Kościól, państwo i rodzinę. Strawińska skoncentrowała uwage czytelniczek na kwestii włączenia tej kwestii w spójne i kompletne nauczanie szkolne, gdzie na każdych zajęciach, począwszy od lekcji religii, literaturoznawstwa czy historii, a skończywszy na lekcjach matematyki, należało wdrażać młodzież do myślenia kategoriami społecznymi oraz do przygotowania do bezinteresownej działalności dla dobra ogółu ${ }^{31}$. Wykorzystała pojęcie „zmysłu społecznego”, zaczerpnięte $z$ piśmiennictwa Jeana Guittona, francuskiego katolickiego filozofa i teologa, autora pracy Le temps et l'éternité chez Plotin et Saint Augustin. Tłumaczyła, że „zmysł społeczny” może zostać nabyty w trakcie wdrażania dzieci i młodzieży do wypełniania codziennych obowiązków, udzielania pomocy bliźnim, poszanowania ich dobra. Proponowała stosowanie techniki „wychowywania przez przykład”, wskazując na sylwetki wybitnych katoliczek, które swoja praca pro bono udowodniły znaczenie działalności społecznej.

\footnotetext{
31 Strawińska odwołała się do doświadczenia szkolnictwa francuskiego, stwierdzając, że w jego ramach naucza się zawodu, ale też wprowadza kwestie myślenia prospołecznego w różne przedmioty wykładane na lekcjach. Jej zdaniem dobry sposób na powiązanie różnych zadań dydaktycznych polega na tym, że „zadania matematyczne obracają się około problemów związanych z życiem, przy czym nie szczędzi się uczennicom wskazówek praktycznych”, Janina Strawińska, „Społeczne urabianie młodzieży”, Kuźniczanka, nr 1, $1931,10-16$.
} 
Redakcja periodyku zadbała o to, by czytelniczki otrzymywały wiedzę o działalności europejskich intelektualistów toczących debatę publiczna na temat stanu chrześcijaństwa w czasach kryzysu wartości, rozkładu moralności, upadku obyczajowości tradycyjnej, co wiązano $z$ następstwami Wielkiej Wojny 1914-1918, postępami komunizmu oraz społecznymi skutkami wielkiego kryzysu gospodarczego. Korzystając z materiałów KAP, w 1933 r. przedstawiono relację z debaty, która prowadził niemiecki etyk Friedrich Wilhelm Foerster $z$ bezimiennym wolnomyślicielem, dezaprobującym religijne podłoże życia ludzkiego. Czytelniczki miały okazję zapoznać się $z$ refleksjami na temat znaczenia chrześcijaństwa w walce $z$ ludzkim egoizmem, $z$ immoralizmem, $z$ konfliktami prowadzacymi do wybuchu wojny. Myśliciel był znany $z$ dażności do łagodzenia napięć w relacjach polsko-niemieckich, w wielu miejscach wypowiadał się na temat możliwości zmniejszenia nacjonalistycznych żądań Niemców wobec Polski. Dialogowa forma tekstu przytoczonego w „Kuźniczance” ułatwiała zrozumienie wywodu, skłaniając do dalszych, samodzielnych rozważań słów Foerstera, który prezentował religijne podwaliny pedagogiki urzeczywistnionej w codziennym działaniu człowieka ${ }^{32}$.

Lektura czasopisma dostarczała wiadomości o bieżącej pracy Kongregacji Oratorium Św. Filipa Neri, stowarzyszenia księży katolickich wywodzącego swój rodowód z XVI w. Członkowie Kongregacji propagowali wizję chrześcijaństwa jako religii radości połączonej z głęboka wiara. Swoja działalność koncentrowali na wychowywaniu młodego pokolenia. Generałowa Zamoyska poznała ich sposób organizacji placówek edukacyjnych w postaci „szkół życia chrześcijańskiego” i dostosowała do warunków istnienia żeńskich szkół gospodarczych na ziemiach polskich. Na łamach „Kuźniczanki” co pewien czas wzmiankowano o osiagnięciach myśli oratorian, spośród których cenieni byli Gaston Brillet, zakonnik, autor dzieła Propos d'Évangile. Jésus parmi les hommes, oraz Henri Pradel, zakonnik, pedagog, propagator idei integralnego wychowania młodego pokolenia, autor artykułu Les petites vertus de l'éducateur,

32 „Źródła kryzysu - natury duchowej. Dialog prof. Foerstera z wolnomyślicielem”, Kuźniczanka, nr 2, 1933, 29-31. Nauki Friedricha Wilhelma Foerstera były chętnie podawane $\mathrm{w}$ wielu wydawnictwach periodycznych w Polsce celem neutralizowania napięć w kontaktach z mniejszością niemiecka, zob.: „Niemcom w Polsce pod rozwagę”, Echo Gdańskie, nr 83, 1926, 2. 
opublikowanego w piśmie „Oratoriana”33. Gaston Brillet był wielokrotnie cytowany, zwłaszcza gdy odwiedzał Polskę i mieszkał w placówce kuźnickiej. $Z$ jego nauk korzystano przy nauczaniu o Ewangelii, o przemyśleniach dotyczących nabożeństwa, o rozważaniach różańcowych. Przypominano nakazy dotyczące tego, że „życie wewnętrzne chrześcijanina powinno być ciagłym Bożym Narodzeniem"34. Medytacje toczyły się wokół przykazania miłości bliźniego, troski o jego dobro, ponadto ponoszenia ofiary na rzecz innych osób, ponieważ „chrześcijanin to ten, kto zrozumiał, że życie jego musi być ciagła, dobrowolną ofiara" 35 . Henri Pradel był cytowany wówczas, gdy omawiano osobowość wychowawcy i jej wpływ na postawy młodego pokolenia. Redakcja pisma dbała o przypominanie postawy Jadwigi Zamoyskiej i jej następczyń, które zmierzały do pokazania, że życie dobrej katoliczki było radosne, ponieważ spełniała wymogi miłości bliźnich. Dlatego redakcja „Kuźniczanki” wielokrotnie wzmiankowała o tym, że uczennice zakopiańskiej placówki wiodły życie szczęśliwe, objawiane codzienną wesołością, która dzieliły się z innymi osobami.

Kierownictwo „Kuźniczanki” prezentowało stan myśli katolickiej w przestrzeni europejskiej, posługując się omówieniami publikacji intelektualistów $z$ różnych części kontynentu. Przedmiotem zainteresowania redakcyjnego stało się zbiorowe dzieło The Return of Christendom, wydane w 1922 r. w Londynie $z$ epilogiem autorstwa Gilberta Keitha Chestertona, brytyjskiego pisarza katolickiego. W thumaczeniu dokonanym na potrzeby czasopisma przedstawiono jego rozważania na temat zderzenia laickiej postępowości $z$ religijnym tradycjonalizmem. Chesterton wypowiadał się na temat wadliwie rozumianej ewolucji moralnej i obyczajowej skutkującej zanikiem zasad chrześcijańskiego miłosierdzia. Przedmiotem krytyki czynił kapitalizm i jego skutki w postaci procesów industrializmu, urbanizmu i bezwzględnego wyzysku ludzi. Jednak nade wszystko

\footnotetext{
${ }_{33}$ Zgodnie $z$ jego naukami w pracy edukacyjnej zalecano przestrzeganie następujacych zasad efektywnej pracy: akuratności, entuzjazmu, obowiąkowości, solidarności koleżeńskiej, zapału, „Małe cnoty wychowawcy. (Według o. Pradel)”, Kuźniczanka, nr 3, 1933, 49-53.

34 „Różaniec życia”, Kuźniczanka, nr 1, 1936, 4. „W okresie Bożego Narodzenia: z nauk o. Brillet”, Kuźniczanka, nr 1, 1931, 6-9; „Kobieta - chrześcijanka - apostołka”, Kuźniczanka, nr 9, 1931, 172-173; Gaston Brillet, Msza święta, „Kuźniczanka”, nr 1, 1933, 6. Dla podkreślenia łączności $z$ duchownym wydrukowano list, w którym zwracał się bezpośrednio do wychowanek Szkoły, „List ojca Brillet”, Kuźniczanka, nr 1, 1936, 6-8.

35 „Różaniec życia”, Kuźniczanka, nr 1, 1936, 4; „Czuwanie z Chrystusem”, Kuźniczanka, nr 4, 1933, 73-74.
} 
potępił twórców i wykonawców systemu kapitalistycznego, którzy „spustoszyli świat najwstrętniejszym i najnikczemniejszym ateizmem po to, ażeby bezwyznaniowość utorowała drogę zabobonom i szarlatanom"36. Korzystano $z$ jego wypowiedzi, co szczególnie odzwierciedliło się w odwołaniach do jego udziału w ankiecie Gdyby Chrystus wrócił na ziemie ogłoszonej w 1932 r. przez magazyn dla kobiet „Good Housekeeping”. Redakcja „Kuźniczanki” przytoczyła in extenso odpowiedzi Chestertona, starając się pokazać znaczenie chrześcijaństwa dla dziejów ludzkości. Myśliciel zwrócił uwagę na znaczenie encykliki Rerum novarum papieża Leona XIII i ideę chrześcijańskiej polityki społecznej dezaprobującej wyzysk ludzi i zachęcajacej do przestrzegania zasad miłości bliźniego. Chesterton wyraził żal z powodu niedostatku realizacji nauki społecznej zawartej w encyklice, uznając, że ochroniłaby ludzkość przed wieloma złymi działaniami: „A teraz stwierdzam bez najmniejszego wahania, że gdyby współczesny świat usłuchał dobrej rady papieża, udzielonej 40 lat temu, gdyby uczynił wysiłek w kierunku decentralizacji kapitału, nie uciekając się do metod komunistycznych, gdyby prosty, szary człowiek miał możność zostania właścicielem drobnej własności, nie znaleźlibyśmy się w takiej piekielnej matni jak dzisiaj"37. Przekonywał, że nie „chrześcijańska idea zawiodła - zawiedli tylko ci, którzy nie żyją według zasad Chrystusowych"38. Chestertona cytowano $z$ kilku powodów: po pierwsze, był przykładem konwertyty religijnego, który przeszedł droge od anglikanizmu do katolicyzmu, po drugie, wyrażał poglądy tradycjonalistyczno-religijne, po trzecie, upowszechniał idee chrześcijańsko-demokratyczne, po czwarte, krytykował socjalizm i agnostycyzm, sprzeciwiał się relatywizmowi moralnemu. Był zwolennikiem tworzenia drobnej własności prywatnej przeciw koncentracji wielkiej własności w jednych rękach. Należał do współtwórców dystrybucjonizmu, który odrzucał zarówno zasady kapitalistyczne, jak i negował wartości socjalizmu.

Powyżej przytoczone informacje o przekazie prasowym dotyczacym bieżącego rozwoju europejskiej myśli katolickiej i rozważań wybranych intelektualistów świadczyły o sprawności redaktorek i publicystek w przekazywaniu treści wartościowych dla czytelniczek, które wprowadzano w krą refleksyjności religijnej podbudowanej wiedzą filozoficzna,

36 „Powrót chrystianizmu”, Kuźniczanka, nr 1-2, 1935, 20.

37 J.D.Z., „Gdyby Chrystus wrócił na ziemię”, Kuźniczanka, nr 6, 1932, 90.

38 Ibidem. 
pedagogiczną, psychologiczną. Jednak starano się również o oddanie głosu czytelniczkom celem uzyskania świadectwa skuteczności nauk wyniesionych $z$ kursów SPDK. Wspomniana ankieta Rozważania w naszym życiu w 1933 r. dostarczyła informacji o tym, na ile wychowanki Szkoły kontynuowały styl życia wpojony w czasie nauki. Respondentki (łącznie ok. 40 osób) pisały o roli twórczości Jadwigi Zamoyskiej w umacnianiu przekonania o znaczeniu refleksyjności na tematy religijne. Wskazywały na znaczenie rozmyślań nad etyką i moralnością, pisały, że część swojej działalności społecznej przeznaczały na organizowanie pogadanek dotyczacych treści Pisma Świętego, a przeznaczonych dla młodzieży szkolnej w różnych częściach Polski. W niektórych odpowiedziach zawarte były gotowe konspekty wypowiedzi na spotkaniach modlitewnych, w trakcie których zalecano czytanie fragmentów Ewangelii i Listów Apostolskich, następnie zachęcano do inicjowania rozmowy wśród uczestników spotkania, by na finał nastapiło „ujęcie dyskusji bardzo życiowe, praktyczne; dyskusje te pełne życia i harmonii wytwarzają nadzwyczaj miłą atmosferę"39. Wychowanki potwierdzały efektywność nauk przekazanych przez Szkołę i utrwalanych w „Kuźniczance”. Swoim życiem poza okresem szkolnej edukacji dowodziły możliwości skorzystania $z$ wzorca osobowego kobiety łączącej wierzenie religijne $z$ postawą prospołeczną.

\section{Sfera materii: dobra gospodyni domowa}

Celem czasopisma było przyuczenie czytelniczek do wypełniania obowiązków wobec rodziny, w której widziano optymalne środowisko katolickiego wychowania młodego pokolenia, chronienia go przed prąami laickimi i kosmopolitycznymi, przyuczania do obrony religii i narodu. Przy definiowaniu rodziny podstawa była encyklika Casti connubii papieża Piusa XI z 31 grudnia 1930 r. Znalazły się w niej kwestie zwiąane ze świętościa związku małżeńskiego, $z$ potępieniem sztucznej kontroli urodzeń i stosowania aborcji. W „Kuźniczance” ze stycznia 1931 r. na podstawie encykliki podawano, że rodzina jest społecznością stanowiąca „kolebkę ustroju społecznego” oraz „szkołę cnót i charakterów”40.

39 „Rozważania w naszym życiu”, Kuźniczanka, nr 2, 1933, 35-36.

40 „Rodzina”, Kuźniczanka, nr 1, 1931. Było tam zalecenie: „Dobro i szczęście rodziny jest pobudka i celem wszelkich przedsięwzięć i prac społecznych”; zob. też: J.D.Z., „Z listu Generałowej Zamoyskiej do swej wychowanki”, Kuźniczanka, nr 6, 1932, 91-92; „List śp. 
Celem wszechstronnego ukazania problematyki rodziny relacjonowano przebieg belgijskiego kongresu zorganizowanego przez katolickich lekarzy z udziałem teologów i socjologów w listopadzie $1931 \mathrm{r}$. W trakcie kongresu omawiane były zagadnienia zwiazane ze zmianami demograficznymi, w tym ze zjawiskiem zmniejszenia się liczby urodzeń. Zwrócono uwage na ekonomiczne uwarunkowania spadku przyrostu naturalnego ludności w powojennych warunkach bezrobocia, drożyzny, inflacji, a następnie w czasie wielkiego kryzysu gospodarczego, który spowodował głębokie zmiany społeczne. Winą obciążono szefów państw lekceważących potrzeby rodzin. Czytelniczkom przedkładano kwestię oczekiwań etyczno-moralnych ze strony społeczeństwa (konieczność otoczenia rodziny stosownym szacunkiem) oraz oczekiwań materialnych, których spełnienia wymagano od agend państwowych w postaci systematycznie przyznawanych zapomóg pieniężnych. Wskazywano, że organy władzy publicznej nie powinny traktować jako „rodzaju jałmużny” tychże zapomóg, majacych stanowić szansę na godne życie ubogich rodzin ${ }^{41}$. Przy takich okazjach redakcja periodyku przypominała sprzeciw katolickich organizacji kobiecych, szczególnie Międzynarodowej Unii Stowarzyszeń Kobiet Katolickich, wobec „praktyk neomaltuzjańskich”, opartych na przekonaniu o ryzyku przeludnienia globu ziemskiego i konieczności prowadzenia polityki zrównoważonego rozwoju demograficznego, kontroli urodzeń i świadomego macierzyństwa.

$\mathrm{Na} ł a m a c h$ pisma tłumaczono, że realizowanie powinności domowych nabrało cech szczególnych, co wymagało profesjonalnego przygotowania przyszłych pań domu, spełniających rolę żony i matki. Jednak szczególną uwagę poświęcono zawodowemu przygotowaniu zarządczyń, zatrudnianych do prowadzenia gospodarstwa domowego czy też do organizowania życia parafialnego w ramach Akcji Katolickiej. Wzorzec kobiecości miał jednoznacznie ukonkretnione atrybuty, jak: Polka, katoliczka, „przedstawiająca wartość moralna, skłonna do poświęceń”42. Uwagę koncentrowano na edukacji szkolnej, ale też na działalności w katolickich

Jen. Zamoyskiej o małżeństwie”, Kuźniczanka, nr 4, 1933, 83-84; „Pamiętniki Generałowej Zamoyskiej. Paryż - obowiąki rodzinne”, Kuźniczanka, nr 1-2, 1935, 1-9.

41 „Obrona rodziny przez socjologię i biologię”, Kuźniczanka, nr 6, 1932, 93; „Matka Dobrej Rady”, Kuźniczanka, nr 2, 1933, 25-28.

42 „Program kursu dla pomocnic parafialnych w Suchem koło Poronina”, Kuźniczanka, nr 3, 1933, 67. W efekcie pozyskano umiejętności takie, jak: prowadzenie kartoteki parafialnej, dbałość o bibliotekę (czytelnię i wypożyczalnię), utrzymywanie w porządku szat liturgicznych, przygotowanie świątyni do nabożeństw, prowadzenie pogadanek dla dzieci 
stowarzyszeniach społecznych, które pomagały pogłębić umiejętności praktyczne. Dla ułatwienia nauki redakcja czasopisma propagowała nowoczesne formy przekazu treści edukacyjnych. Upowszechniała informację o możliwości pozyskania wiedzy za pośrednictwem uczestnictwa w kursie korespondencyjnym, który był zorganizowany celem wyrównania różnic w dostępie do oświaty. Takie działanie miało umożliwić naukę czytelniczkom ze środowiska wiejskiego, by mogły uzyskać stosowna wiedzę mimo ograniczeń spowodowanych trudnościami transportowo-komunikacyjnymi. Zastrzegano, że „kurs nasz zamierzamy utrzymać na poziomie przystępnym dla każdej przeciętnie wykształconej kobiety, bez zapuszczania się w dociekania filozoficzne, ale raczej ujmując rzeczy praktycznie"43.

We wzorcowy wizerunek kobiety wkomponowane były cechy rozumnej żony i matki, fachowej organizatorki życia codziennego, troskliwej i roztropnej opiekunki osób słabszych, niekiedy wykluczonych społecznie. Wszelkie przejawy naukowego podejścia do rodziny były natychmiast odnotowane, jak to było w wypadku publikacji książki poświęconej zagadnieniu profesjonalnej organizacji pracy $\mathrm{w}$ gospodarstwie domowym. Podstawa do rozważań prasowych była praca, która napisała Christine Frederick, a spolszczyła Maria Romanowa, redaktorka miesięczników „Organizacja Gospodarstwa Domowego” oraz „Pani Domu". Celem było przyuczenie do racjonalnego ujmowania zagadnień codziennych czynności domowych, zwiększenia wydajności pracy przy porząkowaniu najbliższego otoczenia, wdrażania do poznania i zastosowania zasad ergonometrii w trakcie przedsięwzięć służących obsłudze domowników. Z książki Naukowa organizacja $w$ gospodarstwie domowym przyswajano konkretne wskazówki, jak: „zmniejszenie ilości ruchów, użycie najlepszych narzędzi dla naszych rąk, odpowiednie rozmieszczenie przedmiotów, które powinny być dostosowane do wysokości pracującego" ${ }^{44}$.

i młodzieży, organizowanie formacyjne parafian (zwracano uwage na powołanie i prowadzenie lokalnych stowarzyszeń katolickich), prowadzenie pracy charytatywnej.

43 „Kurs przez korespondencję”, Kuźniczanka, nr 1, 1931, 17.

${ }_{44}$ Christine Frederick, Naukowa organizacja w gospodarstwie domowym (The New Housekeeping), tłum. Maria Romanowa, (Warszawa: Instytut Naukowej Organizacji przy Muzeum Przemysłu i Rolnictwa, 1926). Redakcja pisma podawała jednoznacznie brzmiace zalecenia usystematyzowane w dwunastu zasadach: ,jasno wytknięty cel; zdrowy sad; rada kompetentna; znormalizowany porzacdek w przebiegu działania; znormalizowane warunki pracy; obliczenie czasu trwania każdej czynności; znormalizowane czynności, 
Sprawa była potraktowana priorytetowo, szczególnie wówczas, gdy chodziło o złagodzenie negatywnych emocji zwiazanych $z$ „plaga porządków”. Taki tytuł nosił tekst publicystyczny, określając jednoznacznie stosunek do prozaicznych prac kobiecych. Autorka pogadanki dała wyraz swoich uczuć, gdy stwierdziła, że „gospodarstwo jest to zło konieczne, które zawisło nad głową każdej kobiety. Rodzi się ona przeznaczona do

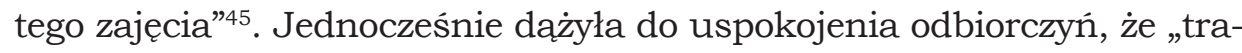
gifarsę życia rodzinnego" można było rozwiązać wspólnymi siłami, gdy proponowała zorganizowanie narady familijnej, ustalenie tygodniowego planu pracy, a nade wszystko zracjonalizowanie działań przez wprowadzenie odpowiedniej metodyki pracy. Kwestia „unaukowienia” problemu wiazała się z zapoznawaniem czytelniczek $z$ zasadami koordynacji działań na rzecz ustanowienia ładu w sprawach prozaicznych, ale składających się na życie jednostki ludzkiej. W periodyku pokazywano możliwość wprowadzania udogodnień przez zakup piekarnika elektrycznego, zainstalowanego w Szkole dla pełniejszego nauczania sprawności zawodowych. Przyuczano do prawidłowego użytkowania sprzętu domowego, by zminimalizować ryzyko uszkodzeń. Czytelniczka dowiadywała się o metodzie postępowania $z$ radioodbiornikiem $\mathrm{w}$ trakcie burzy podczas wyładowań atmosferycznych. W klarowny sposób poinformowano ją o tym, jak uziemić domowy sprzęt elektryczny, w jaki sposób zakładać antenę radiową, jak konserwować urządzenia użytku domowego ${ }^{46}$. Niektóre przykłady czerpano z różnych części świata, przykładowo ze Szwecji, gdy wypowiadano się o schludności skandynawskich domostw, o estetyce życia codziennego, o pożytkach ze stosowania „szwedzkiego stołu”, przy którym można się zdrowo i niedrogo pożywić rozmaitym jadłem. Dla czytelniczek ważne też były informacje o stosowanych w Szwecji metodach prowadzenia kobiecego gospodarstwa wiejskiego, o drobiarstwie, ogrodnictwie, warzywnictwie ${ }^{47}$.

Zapoznanie się $\mathrm{z}$ zasadami logistyki pracy domowej było traktowane jako przejaw odpowiedzialnej działalności o ponadjednostkowej

rozkład zajęć; dokładny rejestr; karność; sprawiedliwe i uczciwe postępowanie; nagroda za wydajność”, „Naukowa organizacja pracy w gospodarstwie domowym”, Kuźniczanka, nr 3, 1931, 63.

45 Zofia Zdanowska, „Plaga porzadków”, Kuźniczanka, nr 2, 1934, 40.

46 „Z życia szkolnego w Kuźnicach”, Kuźniczanka, nr 1-2, 1935, 14-15; „Wyładowania atmosferyczne a radio", Kuźniczanka, nr 5, 1932, 86-87.

47 Teresa Leszczyńska, „Z wędrówki po świecie. Szwecja”, Kuźniczanka, nr 9, 1931, 186. 
wartości. Niemal w każdym numerze „Kuźniczanki” pojawiały się informacje o efektach pracy edukacyjnej w Szkole. Wynikało z nich, że kobieta dobrze przygotowana do pracy domowej umiała sporzązać odzież, szyć komplety bielizny dziecięcej i damskiej, znać reguły kroju fasonów sukien damskich, wykonywać robótki ręczne szydełkiem i na drutach, wykonywać hafty. Propagowano grupe przedmiotów nauczania porząków, gdzie przysposobiono do dbałości o domostwo i sprzęty użyteczności domowej (konserwowanie mebli, czyszczenie przedmiotów ze srebra). Ceniono dział kulinariów zarówno przy przyrządzaniu dań mięsnych (opisywano stoły zastawione „mięsiwem, rybami, pasztecikami”), jak i szykowaniu deserów. Popisowe wytwory działalności własnej uczennic jako rodzaj pracy dyplomowej były udostępniane gościom i publiczności podczas wystaw w przeddzień zakończenia roku szkolnego ${ }^{48}$. O autentyzmie przekazu świadczyły wypowiedzi wychowanek, których teksty drukowano głównie w postaci sprawozdań z życia Szkoły. Były podpisane nazwiskiem $z$ adnotacja „uczestniczka II kursu instruktorek”. Rubryki służyły utrzymywaniu kontaktu z czytelniczkami, rozwijaniu umiejętności interakcyjnych i propagandowych. Spełniały podwójna funkcję komunikacyjną w postaci podtrzymywania łączności $z$ wychowankami oraz upowszechniania wiedzy o $\mathrm{SDPK}^{49}$. Wspomniano już o ankiecie Co mi dały Kuźnice? Odpowiedzi dostarczyły absolwentki, a redakcja dbała o atrakcyjność przekazu, stosując m.in. formułę kontrastowania tekstu pod względem czasu, jakiego dotyczyły wspomnienia. Przykładowo, w pierwszym podejściu zestawiono wspomnienia sprzed 30, 20 i 10 lat, by czytelniczkom przybliżyć okoliczności kształcenia postaw wychowanek Szkoły. Zamieszczano wypowiedzi respondentek, potwierdzających, że realizowały kilka zadań: integrowanie środowiska katoliczek, wzmacnianie wiarygodności, udowadnianie funkcjonalnego i skutecznego efektu edukowania w SDPK. Znajdowały się w nich informacje o działaniach adaptacyjnych absolwentek Szkoły, o kontynuowaniu pracy praktycznej, do której przygotowały się w trakcie nauki szkolnej. Część dawnych

\footnotetext{
48 „Kronika”, Kuźniczanka, nr 3, 1933, 60.

49 Dział Głosy Kuźniczanek był przemyślany: „otwierając niniejszą rubrykę, uprzejmie prosimy o dalsze głosy. Jeżeli pismo nasze ma ogniskować myśli, pragnienia i potrzeby kuźniczanek, jeżeli ma istnieć i rozwijać się i być echem Zakładu, rozchodzacym się po najdalszych zakątkach Polski, konieczna jest rzecza, aby Kuźniczanki zasilały ją nie tylko przez prenumeratę, ale i przez współpracę”, „Głosy Kuźniczanek”, Kuźniczanka, nr 2, 1934, 36; W.K., „Kuźniczanka nie kuźniczanka”, Kuźniczanka, nr 1-2, 1935, 12-13.
} 
uczennic zakładała placówki oświatowe, by upowszechniać idee katolickiej pracy edukacyjnej wśród dziewcząt ${ }^{50}$.

Dobroć, łagodność, skromność, uprzejmość były propagowane jako komponenty wizerunku wychowanki Szkoły. W jej opisie znajdował się schludny ubiór, bez dbałości o światową elegancję, ale $z$ troska o czystość i funkcjonalność szaty. Podkreślano, że nawet do uroczystych spotkań „każda przywdziewa granatowy mundurek, czysty czepek i takiż fartuszek. Taki to już w Kuźnicach obyczaj, że do wieczerzy wigilijnej zasiadamy jednakowo ubrane" ${ }^{51}$. Jak wspomniano, wychowanka była przygotowana do tego, by upowszechniać model postępowania wypełnionego obowiazkami wobec siebie, bliskich oraz społeczeństwa.

Twórczy wysiłek, praca umysłowa i fizyczna, wspomniane już rozważania o sprawach religijnych, udział w rekolekcjach, słuchanie nauk katechetycznych - te wszystkie czynności majoryzować miały życie katoliczki chcącej pogłębiać wiedzę o życiu własnym oraz o bliźnich. Dobra gospodyni była też świetna zarządczynią wolnego czasu, który należało zagospodarować $z$ pożytkiem dla rozwijania ducha i dla odpoczynku fizycznego. Na ten temat stale publikowano w „Kuźniczance” obszerne sprawozdania i kroniki, szczególnie gdy prezentowano życie Szkoły w czasie karnawału. Stosowano praktyczne przygotowanie do organizowania rozrywek, ponieważ czytelniczki były informowane o tym, że uczennice w przerwach od nauki zajmowały się „szlachetnym sportem narciarskim”, wśród rozrywek były wyprawy do kina na „film mniej lub więcej zajmujący", wreszcie karnawałowy bal szkolny. Słuchaczki kursu miały zagwarantowane rozrywki: kuligi, wycieczki krajoznawcze, obserwację skoków narciarskich czy skijöringu (zawody polegające na wyścigu narciarzy ciagniętych przez psy). Szczególnym wydarzeniem był ślub wychowanki w kaplicy kuźnickiej z udziałem kierownictwa Szkoły ${ }^{52}$.

\footnotetext{
50 „Odpowiedź na ankietę Co mi dały Kuźnice?”, Kuźniczanka, nr 3-4, 1934, 59-63. Były też dowody zmysłu przedsiębiorczości, o czym świadczyła reklama nowo wybudowanego pensjonatu w Zakopanem $z$ adnotacją, że właścicielką była dawna kuźniczanka, „Pensjonat w Zakopanem", Kuźniczanka, nr 6, 1932, 96.

51 „Święta Bożego Narodzenia w Kuźnicach”, Kuźniczanka, nr 2, 1931, 39.

52 „Z życia szkolnego w Kuźnicach”, Kuźniczanka, nr 1-2, 1935, 14-15; B., „Dziękujemy Wam, Kuźnice”, Kuźniczanka, nr 1, 1936, 12-13; „Sprawozdania Kółek Pracy Społecznej w Kuźnicach za rok 1932/1933”, Kuźniczanka, nr 3, 1933, 64-66; „O 50-ciu szczęśliwych studentkach”, Kuźniczanka, nr 3-4, 1934, 63-64; W.K., „Śmiej się, śmiej wieku młody”, Kuźniczanka, nr 1-2, 1935, 22-23; „Kronika. Z życia Kuźnic”, Kuźniczanka, nr 2, 1936, 26; „Głos najmłodszych”, Kuźniczanka, nr 2, 1933, 41-42.
} 
Systematycznie informowano o nowościach wydawniczych. W 1936 r. rekomendowano czytelniczkom lekturę książek poświęconych tematyce kobiecej. Polecano cykl powieściowy, który napisała Jo van Ammers-Küller, holenderska powieściopisarka. Jej utwory były zalecane $z$ dwóch powodów, po pierwsze, ponieważ były popularne (czytała je „młodzież żeńska całego świata"), po drugie, ich fabuła dotyczyła życia kobiet, obecności w rodzinie i społeczeństwie. Rekomendacja dotyczyła tych fragmentów książek, w których autorka zalecała: „niech się kobieta kształci ogólnie i zawodowo, niech umie żyć samodzielnie, ale również niech umie dobrowolnie zrzec się części tej samodzielności, jeśli chce budować szczęśliwa rodzinę"53. Przekaz dla czytelniczek był klarowny i wiazał się z gotowościa do kształtowania kobiety, która poradzi sobie w trudnych sytuacjach życiowych. Kreowano model kobiety zaradnej, która nie wymagała opieki męskiej, ale zarazem afirmowała tradycyjny porządek społeczny i reguły patriarchalnych relacji między kobietą i mężczyzną.

\section{Zakończenie}

W przekazie zawartym w „Kuźniczance” istniał wizerunek kobiety krzewicielki wiary religijnej w okolicznościach stworzonych przez codzienne życie. Wśród funkcji czasopisma ukierunkowanego na konkretny krag czytelniczek znalazły się działania na rzecz kreowania i upowszechniania pożądanego modelu życia katoliczki w Polsce lat 30. XX w. Redaktorki i publicystki zwracały uwage na funkcję: 1) poznawcza, polegająca na dostarczaniu wiedzy o życiu Jadwigi Zamoyskiej i jej następczyń; 2) wzorcotwórcza, dzięki której umacniano przekonanie o możliwości naśladownictwa ideału wychowawczego; 3) dokumentacyjna, pozwalajaca na utrwalanie przejawów życia społecznego, kulturalnego i religijnego; 4) edukacyjno-socjalizacyjna związana $z$ wychowywaniem oraz przekazywaniem tradycji nauczania młodego pokolenia; 5) integracyjną wokół idei katolickiej służby publicznej; 6) perswazyjna, której celem było oddziaływanie na styl myślenia i sposób postępowania czytelniczek; 7) mobilizacyjna, dzięki czemu u odbiorczyń wywołano pożądane zachowanie społeczne; 8) rozrywkowa, gdy włączano czytelniczki w formy zabawy i rekreacji.

53 ZJ, „Na marginesie przeczytanej książki”, Kuźniczanka, nr 1, 1936, 15. 
W czasopiśmie propagowane były postawy i zachowania kobiece podyktowane przez normy religijne. Trwała promocja stylu życia bogobojnego, cnotliwego, pracowitego, skromnego. Prasowy wzorzec kobiety miał wpływać na uformowanie zastępu pań odpowiednio przygotowanych do pełnienia ról społecznych wyznaczonych płcia, biologia, tradycja, wierzeniem religijnym, a ponadto miał dostarczyć konkretnych wartości do naśladowania. Zawierał postulatywny obraz cech kobiecych uwarunkowanych kulturowo i osadzonych w realiach społecznych pierwszych dekad XX w. na ziemiach polskich. Służył mobilizowaniu obrończyń wartości religijnych i narodowych, tradycjonalizmu obyczajowego oraz wyszkoleniu duchowemu celem prowadzenia apostolstwa świeckiego. Tworzenie modelu idealnej kobiety miało wymiar ponadjednostkowy, ponieważ odpowiednio wyedukowana i przygotowana do swoich ról społecznych żona i matka tworzyła optymalne warunki rozwoju młodego pokolenia, ogniskowania pracy dla dobra wspólnoty. Periodyk uczestniczył w procedurze kształtowania kultury pracy domowej, z której uczyniono przedmiot profesjonalizacji edukowania i realizowania.

Periodyk „Kuźniczanka” realizował kilka zadań, wśród których znalazły się kwestie: 1) kształtowania świadomości i więzi wewnętrznej między czytelniczkami i redakcją czasopisma; 2) promowania dorobku edukacyjnego i doświadczenia wychowawczego; 3) integracji uczennic i absolwentek w ramach katolickiego systemu wartości; 4) aktywizacji w działalności pro bono na rzecz własnego otoczenia; 5) kształtowania kapitału wiedzy religijnej i obywatelskiej; 6) budowania spójności społecznej; 7) rekonstruowania, utrwalania i upowszechniania historii placówki i jej założycielki; 8) umacniania tożsamości Szkoły i związanej z nią symboliki. 


\section{Bibliografia}

\section{Źródła}

Echo Gdańskie 1926.

Kuźniczanka 1931-1936.

Ogniwo 1937.

Pisemko Kuźniczanek 1924-1930.

Czaplicka, Mieczysława. Moje wspomnienia. Szkoła Pracy Domowej w Zakopanem-Kuźnicach, (Kraków: Wydawnictwo Instytutu Teologicznego Księży Misjonarzy, 1964), 198.

Frederick, Christie. Naukowa organizacja w gospodarstwie domowym (The New Housekeeping), thum. Maria Romanowa, (Warszawa: Instytut Naukowej Organizacji przy Muzeum Przemysłu i Rolnictwa, 1926).

Spis gazet i czasopism Rzeczypospolitej Polskiej 1922, (Warszawa: Biuro Ogłoszeń Polska Agencja Reklamy, 1922).

Spis gazet i czasopism Rzeczypospolitej Polskiej oraz poradnik reklamowy. Rocznik 1924/25, (Warszawa: Biuro Ogłoszeń Teofil Pietraszek, 1924).

Spis gazet i czasopism Rzeczypospolitej Polskiej oraz poradnik reklamowy na rok 1932, (Warszawa: Biuro Ogłoszeń Teofil Pietraszek, 1932).

Zamoyska, Jadwiga. Słowa Pisma Świętego podane do rozmyślania. 3, (Leviticus: Księga Kapłańska), (Poznań: Zakład Kórnicki, 1918).

Zamoyska, Jadwiga. Zakład Kórnicki. (Szkoła Domowej Pracy w Zakopanem), (Poznań: Biblioteka Kórnicka, 1898).

Zamoyska, Jadwiga. Zakład Kórnicki. (Szkoła Domowej Pracy w Zakopanem). O trzech oddziałach, (Poznań: Biblioteka Kórnicka, 1900).

Zamoyska, Maria. Jak powstało dzieło śp. Jenerałowej Zamoyskiej, (Kórnik: Zakłady Kórnickie, 1927).

\section{Opracowania}

Bednarz, Mariola Bogumiła. „Hrabina Jadwiga Zamoyska: założycielka Kuźnickiej Szkoły", Karkonosze, nr 2, 2011, 32-33.

Chrapek, Jan. „Kościół wobec środków społecznego komunikowania”, Ethos, nr 4, 1989, 230-245. 
Czachowska, Katarzyna. Generałowa Jadwiga Zamoyska (1831-1923). Życie i dzieło, (Poznań: Wydawnictwo Poznańskie, 2011).

Dziki, Sylwester. „Prasa wyznaniowa”, w: Walery Pisarek (red.), Stownik terminologii medialnej, (Kraków: Towarzystwo Autorów i Wydawców Prac Naukowych „Universitas”, 2006), 156.

Gloger, Marek. „Prasa parafialna”, w: Edward Chudziński (red.), Słownik wiedzy o mediach, (Warszawa: Wydawnictwo Szkolne PWN, 2007), 149.

Guzek, Damian. Media katolickie w polskim systemie medialnym, (Torun: Wydawnictwo Adam Marszałek, 2016).

Lachendro, Jacek. „Prasa powiatów górskich województwa krakowskiego w latach 1918-1939", Rocznik Historii Prasy Polskiej, nr 3, 2000, 35-67. Lechicki, Czesław. „Polska prasa katolicka 1945-1948”, Kwartalnik Historii Prasy Polskiej, nr 2, 1983, 65-84.

Lechicki, Czesław. „Prasa kościelna, prasa religijna, prasa wyznaniowa”, w: Julian Maślanka (red.), Encyklopedia wiedzy o prasie, (Wrocław: Zakład Narodowy im. Ossolińskich, 1976), 174, 182, 191.

Lepa, Adam. Katalog prasy katolickiej w Polsce, (Łódź: Archidiecezjalne Wydawnictwo Łódzkie, 1994.

Sokołowski, Marek (red.), Blask religii. Media w poszukiwaniu sacrum i autorytetów, (Torun: Wydawnictwo Adam Marszałek, 2016).

Maj, Ewa. „Kobieta wobec polityki: strategie tożsamościowe w publicystyce tygodnika Na Posterunku (1917-1919)", w: Małgorzata Dajnowicz, Adam Miodowski (red.), Polityka i politycy $w$ prasie XX i XXI wieku. Polityka $w$ prasie kobiecej, (Białystok: Wydawnictwo Uniwersytetu w Białymsto$\mathrm{ku}, 2019), 43-56$.

„Wzorzec roli, model roli”, w: Maxine Molineux et al., Stownik socjologii i nauk społecznych, red. Gordon Marshall, red. nauk. wyd. pol. Marek Tabin, red. Alina Kapciak, tłum. Henryk Banaszak, (Warszawa: Wydawnictwo Naukowe PWN, 2005), 432.

„Żelska-Mrozowicka Zofia”, w: Grażyna Bral (red.), Słownik dziennikarzy i publicystów Pomorza 1945-2005, (Gdańsk: Stowarzyszenie Dziennikarzy Rzeczypospolitej Polskiej, 2008), 197. 